\title{
ПРАВОВОЕ ОБЕСПЕЧЕНИЕ ЭФФЕКТИВНОГО ИСПОЛЬЗОВАНИЯ СОБСТВЕННОСТИ РОССИЙСКОЙ ФЕДЕРАЦИИ ЗА РУБЕЖОМ
}

Аннотация: В статье рассматриваются теоретические и практические аспекты правового обеспечения контроля государства за эффективностью использования имущества, которое находится на территории иностранных государств. В работе анализируется правовое положение субъектов управления собственностью Российской Федерации за рубежом, а также их деятельность по повышению эффективности использования таких объектов. Отдельный акцент был сделан на анализе Указа Президента Российской Федерации о мерах по улучшению использования расположенного за пределами Российской Федерации федерального недвижимого имущества, закрепленного за федеральньми органами исполнительной власти и их представительствами, другими государственньми органами Российской Федерации и государственными организациями, главной иелью которого являлось повышение экономической эффективности использования федерального недвижимого имущества, а также создание четкой системы учета имущества, обеспечения его правовой защчиты и прозрачности финансовых потоков. Был сделан вывод о низкой эффективности управления недвижимым имуществом государства за рубежом.

Review: The article is devoted to theoretical and practical aspects of legal guarantees of state control over the efficiency of use of its property situated in the territories of the foreign states. The article includes analysis of the legal position of the property administration subjects for the property of the Russian Federation abroad, as well as their activities aimed to improve the efficiency of use of such objects. Special attention was paid to the analysis of the Decree of the President of the Russian Federation on the measures for the improvement of the use of the federal property of the Russian Federation, which is situated outside the Russian Federation and which is settled on the federal executive bodies, their representatives, other bodies of the Russian Federations, and state organizations. The main goal of this Decree was to improve economic efficiency of the use of the federal immovable property and to achieve clarity of the property recording system, guarantee its legal protection and transparency offinancial streams. The conclusion was then made on the low efficiency of management of immovablepropertyof the state abroad. Ключевые слова: имущество, государственная собственность, Министерство иностранных дел, Росимущество, унитарное предприятие, эффективность, управление, дипломатическая миссия, иностранная собственность, использование государственной собственности

Keywords: property, state property, the Ministry of Foreign Affairs, the Federal Property Management Agency, the unitary enterprise, efficiency, administration, diplomatic mission, foreign property, use of state property.

опросы повышения эффективности управления федеральной собственностью за рубежом имеют первостепенное значение, приоритетность которого определена Постановлением Правительства Российской Федерации «О Концепции долгосрочного социально-экономического развития Российской Федерации на период до 2020 г.» ${ }^{1}$, в котором указано на необходимость осуществления формирования эффективной системы управления государственной собственностью при соблюдении соответствия состава государственного имущества функциям государства и повышения эффективности государственного сектора экономики».

\footnotetext{
${ }^{1}$ Распоряжение Правительства РФ от 17.11.2008 № 1662-р «О Концепции долгосрочного социально-экономического развития Российской Федерации на период до 2020 года» // С3 РФ, 24.11.2008, № 47, ст. 5489
}

В отчете об эффективности управления и эксплуатации имущества за рубежом и ее учета, который был подготовлен Счетной палатой в 2013 г. ${ }^{2}$, было установлено, что около $12 \%$ общей площади объектов федеральной собственности Российской Федерации на территории других государств фактически не используется, либо используются крайне не эффективно.

Кроме того, был выявлен ряд существенных недостатков в системе управления зарубежной собственностью, к примеру: отсутствие единой государственной базы объектов собственности зарубежом, недостаточ-

\footnotetext{
2 Отчет о результатах контрольного мероприятия «Проверка состояния реестра федеральной государственной собственности на первый и последний день отчетного финансового года в Федеральном агентстве по управлению государственным имуществом» // Архив Бюллетеня Счетной палаты №5. - 2013.
} 
ное нормативное правовое обеспечение управления собственностью России вне её суверенной территории, при этом действующиенормы, регламентирующие управление федеральной собственностью за рубежом, нуждаются в совершенствовании.

В соответствии с п. “Г” ч. 1 ст. 114Конституции РФ $\Phi^{3}$ управление федеральной собственностью,находящейся за рубежом,осуществляется Правительством РФ. Однако список балансодержателей неиспользуемого имущества является более широким по составу, чем это указанно в Конституции РФ, к примеру, к таковым относятся не только ряд министерств и ведомств, но и государственныеунитарные предприятия. Таким образом, к лицам, в ведении которых находятся объекты зарубежной собственности Российской Федерации, можно отнести: МИД России, Управление делами Президента Российской Федерации, Минобороны России, «Росзарубежцентр», Федеральное агентство по управлению государственным имуществом, ФГУП «Росзагрансобственность»УП равления делами Президента РФ, РИА «Вести», ВГТРК, Минсельхозпрод России, Минприроды России и др.

Как видно из приведенного перечня обладателей права управления государственной собственностью за рубежом, область осуществляемой ими деятельности весьма обширна и не имеет между собой прямой связи. Данное обстоятельство крайне усложняет процесс выработки единых норм и стандартов по проведению мероприятий,направленных на повышение эффективности управления такой собственностью.Таким образом, можно считать, что межведомственная разобщенность балансодержателей объектов недвижимости за рубежом и их узковедомственная политикаприводит к недостаточно эффективному и рациональному использованию этого имущества.

Подтверждением данного вывода может служить заявление Управления делами Президента РФ, в соответствии с которым примерно треть федеральной недвижимости за рубежом не использовалась эффективноеще со времен распада СССР.

Анализ выявил, что следствием продолжительного периода не эффективного использования имущества, а также несоблюдения нормативов при размещении госструктур зарубежом стало то, что в ряде стран образовался профицит и дефицит площадей и иного имущества. На основании выявленных недостатков и проведенного исследования представляется, что состояние дел по использованию федерального недвижимого

${ }^{3}$ Конституция Российской Федерации от 12.12.1993 // С3 РФ, 26.01.2009, N 4, ст. 445 имущества Российской Федерации, находящегося на территории различных государств мира, находится в крайне неудовлетворительном состоянии.

В докладе также отмечено, что одним из выходов из сложившейся ситуации может быть принятие решений о покупке, продаже, мене, залоге, дарении недвижимого имущества, находящегося за рубежом и являющегося федеральной собственностью, а также ценных бумаг, долей, паев и акций, принадлежащих Российской Федерации находящихся в зарубежных юридических лицах.

Однако сложность исполнения решений по заключению сделок с имущества РФ за рубежом состоит в том, что нет единого уполномоченного ведомства, которое контролировало бы все иностранное имущество государства.

Как было указано выше, на сегодняшний деньосновные зарубежные активы управляются пятью структурами -Управлением делами Президента РФ, МИДом, Минэкономразвития, Федеральным агентством по управлению государственным имуществом и ФГУП «Ро сзагрансобственность»Управления делами Президента Российской Федерации. МИД контролирует все земли и здания, защищенные Венской конвенцией о дипломатических сношениях 1961 года ${ }^{4}$ и имеющие дипломатический статус, такая недвижимость по нормам международного права предназначена только для дипломатических миссийи не может быть использованы в других целях.

На балансе Минэкономразвития находятся в основном здания торговых представительств, которые также не могут быть использованы в других целях не связанных с их прямым назначением.

Федеральное агентство по управлению государственным имуществом является уполномоченным федеральным органом исполнительной власти, который осуществляет только контроль и регистрацию в области приватизации и полномочий собственника, в том числе права акционера, в сфере управления имуществом Российской Федерации.

Таким образом, остается очень ограниченный перечень собственности и крайне узкое правовое поле, позволяющее свободное использование зарубежной собственности, находящейся под контролем Управления делами Президента РФ и ФГУП «Росзагрансобственность» Управления делами Президента РФ.

Представители различных ведомств указывают на необходимость создания единого государственного реестра собственности и контролирующего органа, реализующего эффективное управление зарубежной собственности, в

${ }^{4}$ Венская конвенция о дипломатических сношениях от 18.04.1961 г. Вена // Ведомости ВС СССР. 29.01.1964 г. N 18. Ст. 221 
DOI: $10.7256 / 1811-9018.2013 .10 .9445$

При цитировании этой статьи сноска на dоі обязательна

\section{Право и политика $10(166) \cdot 2013$}

которое может входить, к примеру, в сдача в аренду недвижимого имущества, находящегося за рубежом и являющегося федеральной собственностью, закрепленного на балансе государственных предприятий и учреждений. По общему правилу такая сделка осуществляется на срок до одного года учреждениями самостоятельно, на срок свыше 5 лет - по решению Правительства РФ 5 .

Однако использовать государственную собственность за рубежом очень сложно по ряду правовых ограничений. К примеру, после распада СССР все бывшие республики подписали так называемый «нулевой вариант» - Россия согласилась взять на себя все долговые обязательства СССР в обмен на владение этим иностранным имуществом, но Украинане заключила соглашение и подала ноту протеста с претензиями на данную собственность. Так как развития ситуации по этому вопросу нет, Россия не может ни продать, ни сдать в аренду большинство своих владений за рубежом, на которые претендует Украинская сторона.

В свою очередь, из-за сложностей с договорной реализации имущества за рубежом было принято решение обучреждении в установленном порядке юридических лиц на основе собственности РФ находящейся на территории иностранных государств ${ }^{6}$. Таким образом, при создании на территории иностранных государств таких акционерных обществ:

1. в состав имущества, на основе которого будет происходить формирование их уставного капитала, неподлежат включению являющиеся собственностью Российской Федерации акции (паи, доли) находящихся на территории иностранных государств юридических лиц;

2. контрольный пакет акций этих акционерных обществ закрепляется в федеральной собственности. Правительству РФ было поручено обеспечить внесение в уставный капитал создаваемых юридических лиц находящихся за границей имущества Российской Федерации по мере высвобождения его для коммерческого использования, а также представить предложения о последующей передаче контрольных пакетов акций создаваемых организаций федеральным государственным унитарным предприятиям для обеспечения эффективного управления акциями․

\footnotetext{
${ }^{5}$ См.: Богуславский M. М. Международное частное право: практикум. - М: Инфра-М, 2010.. - С-368.

${ }^{6}$ Указ Президента РФ от 29 июня 1998 г. № 733 «Об управлении федеральной собственностью, находящейся за границей» // Российская газета. 1998. 1 июля.

${ }^{7}$ См.: Звеков В. П. Международное частное право. Курс лекций. - М.: Издательство НОРМА, 2000. - C - 686.
}

В начале 2000 гг. важнейшим шагом на пути урегулирования проблем по управлению собственностью РФ за границей, а также созданию существующей в настоящее время системы управления и распоряжения федеральным недвижимым имуществом за рубежом стал Указ Президента Российской Федерации от 23 октября 2000 года № 1771 «О мерах по улучшению использования расположенного за пределами Российской Федерации федерального недвижимого имущества, закрепленного за федеральными органами исполнительной власти и их представительствами, другими государственными органами Российской Федерации

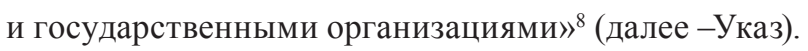

Главной целью Указа являлось повышение экономической эффективности использования федерального недвижимого имущества, а также создание четкой системы учета имущества, обеспечения его правовой защиты и прозрачности финансовых потоков. Для достижения данной цели Указом было определено сосредоточение значительной части госзагрансобственности в Управлении делами Президента Российской Федерации, ачасть имущества, связанная с выполнением дипломатических и консульских функций, по-прежнемуосталась в ведении МИДа России.

В настоящее время управление федеральной недвижимой собственностью за рубежом осуществляется Управлением делами Президента РФ на основании вышеупомянутого Указа, а также ряда других нормативно-правовых актов, в тесном взаимодействии с другими министерствами и ведомствами.

Важным достижением Управления делами Президента стало создание ведомственного реестра зарубежной собственности. К сожалению, в нем не содержится полный перечень иностранной собственности, следовательно, данный реестр не может решить проблему учета всего комплекса иностранного имущества Российской Федерации. Но согласно данному реестру на балансе Управделами Президента около 1 тыс. объектов в 70 странах мира. Почти половина из них находится в дружественных странах Африки и бывших социалистических республиках, также есть достаточное количество объектов в развитых странах, например во Франции, США, Японии. Все эти объекты переписаны, и их состояние

\footnotetext{
${ }^{8}$ Указ Президента Российской Федерации от 23 октября 2000 года № 1771 «О мерах по улучшению использования расположенного за пределами Российской Федерации федерального недвижимого имущества, закрепленного за федеральными органами исполнительной власти и их представительствами, другими государственными органами Российской Федерации и государственными организациями». // С3 РФ, 30.10.2000, N 44, ст. 4352
} 
постоянно контролируется, наиболее нуждающиеся в ремонте здания регулярно ремонтируют.

В целом, несмотря на принятые меры по улучшению ситуации, сохраняющийся процент пустующих объектов недвижимости России за рубежом свидетельствует о низкой эффективности управления недвижимым имуществом.

В указанном выше отчете Счетной палаты называются конкретные объекты недвижимости, неэффективность которых обходится Российской Федерации слишком дорого. Так, ФГУП «РИА Новости» и ФГУП «Информационное телеграфное агентство России»не используют 11 объектов общей площадью 3 тыс. кв. м, переданных этим медиакомпаниям на праве безвозмездного пользования. «В этих объектах должны были размещаться зарубежные представительства «РИА Новости» и ИТАР-ТАСС». Банк ВТБ не приступил к освоению земельного участка площадью 0,8 га в Лондоне по адресу: Уорик Роуд, 245. Этот участок был выделен для коммерческого использования в обмен на обязательство реконструировать и построить здания посольства РФ в Великобританиия.

Печальную статистику пополняют и посольства Российской Федерации. Проверка показала, что они нарушают предписания МИД и иных ведомственных нормативов, занимая больше площади, чем положено, то есть бюджетные средства на содержание помещений тратятся нерационально. Данный факт в очередной раз указывает на несовершенство принятых ранее нормативно-правовых актов, которые в скорейшем темпе требуют пересмотра. Так, слишком просторными, по мнению Счетной палаты, оказались резиденции послов России в Гватемале и Мексике. Их площади превышают установленные нормативы в 2,5 и 3,5 раза соответственно. Комплексы посольств РФ в Белоруссии и Казахстане спроектированы с превышением установленных нормативов от 20 до 70\% по отдельным зданиям.

Приводя пример из опыта иностранных государств, необходимо отметить, что для некоторых стран расточительство и неэффективность содержания зарубежной недвижимости непозволительно дорогое удовольствие. Так, в конце прошлого года стало известно о планах Греции реализовать дипломатическую недвижимость по всей Европе. Конечно, весьма затруднительно представить Россию на месте Греции, однако это не позволяет отодвинуть данную проблему на второй план ${ }^{10}$.

\footnotetext{
${ }^{9}$ См.: Ахмадиева A. Счетная палата нашла нарушения в российских посольствах / Газета ИЗВЕСТИЯ. 16.052013

${ }^{10}$ Cм.: Jennifer Rankin and Helena Smith. «Greek consul's London villa fetches $£ 23.3 \mathrm{~m}$ as part of state’s fire sale» - The Guardian, Thursday 4 April 2013 17.55 BST
}

Положительным фактором в данном вопросе выступает реализация единого подхода к содержанию и эксплуатации объектов федерального недвижимого имущества за рубежом. На регулярной и плановой основе осуществляются капитальные и текущие ремонты недвижимости, производится ее ежегодное страхование, а эффективно реализованное коммерческое использование части недвижимого имущества, не задействованного для размещения представительств Российской Федерации, государственных органов и организаций, позволяет снижать нагрузку на федеральный бюджет путем финансирования существенной части расходов по содержанию всего федерального недвижимого имущества за рубежом.

\section{Библиография:}

1. Богуславский М. М. Международное частное право: практикум. - М: Инфра-М, 2010.. - С-368.

2. Звеков В. П. Международное частное право. Курс лекций. - М.: Издательство НОРМА, 2000.

3. Ахмадиева А. Счетная палата нашла нарушения в российских посольствах / Газета ИЗВЕСТИЯ. 16.052013

4. Отчет о результатах контрольного мероприятия «Проверка состояния реестра федеральной государственной собственности на первый и последний день отчетного финансового года в Федеральном агентстве по управлению государственным имуществом» // Архив Бюллетеня Счетной палаты 2013, №5.

5. Jennifer Rankin and Helena Smith. «Greek consul's London villa fetches $£ 23.3 \mathrm{~m}$ as part of state’s fire sale»-The Guardian, Thursday 4 April 2013 17.55 BST

\section{References (transliteration):}

1. Boguslavskii M. M. Mezhdunarodnoe chastnoe pravo: praktikum.-M: Infra-M, 2010..-S-368.

2. Zvekov V. P. Mezhdunarodnoe chastnoe pravo. Kurs lektsii.-M.: Izdatel'stvo NORMA, 2000.

3. Akhmadieva A. Schetnaya palata nashla narusheniya v rossiiskikh posol'stvakh / Gazeta IZVESTIYa. 16.05 2013

4. Jennifer Rankin and Helena Smith. «Greek consul's London villa fetches $£ 23.3 \mathrm{~m}$ as part of state's fire sale»-The Guardian, Thursday 4 April 2013 17.55 BST 